\title{
Commercial Bank Loans and the Performance of Small and Medium Scale Enterprises (SMEs) In Nigeria
}

\author{
${ }^{1}$ Kanu Success Ikechi, ${ }^{2}$ Nwadiubu Anthony \\ ${ }_{1,2}^{2}$ Department of Banking and Finance, Faculty of Social and Management Sciences, Eastern \\ Palm University, Ogboko Ideato,P.M.B 6, Orlu Imo State. Nigeria
}

\begin{abstract}
The contributions of Small and Medium Scale Enterprises (SMEs) to the growth of Nigerian economy cannot be understated as they seem to drive the economic and industrial transformation of the country. Notwithstanding the acknowledged role of SMEs, a number of factors tend to limit their growth potentials. They're still faced with the issue of funding and to overcome this problem, external borrowing has become inevitable. Commercial banks appear to be the most likely source of funds. Thus, the main objective of this study is to ascertain the impact of commercial bank loans on the performance of small and medium scale enterprises in Nigeria. While an ex-post facto research design was adopted in the investigation; a least square regression analysis was carried out on a time-series data to ascertain relationships, and to avert the emergence of spurious results, unit root tests were conducted. Outcome of the study indicates that, there exists an inverse relationship (though not statistically significant) between the amount of commercial bank loans (CBLSME) made available to SMEs and the output of SMEs (OPSME) in Nigeria This implies that as CBLSME increases, OPSME decreases. The negative sign exhibited by OPSME is not in line with our apriori expectation because an increase in CBLSME is supposed to cause an increase in investment which is expected to boost the output of SMEs. This trend has shown the poor attitude of commercial banks towards the granting of loans to SMEs in Nigeria. The study also revealed that a seeming upsurge in the activities of SMEs may not have reduced the rate of unemployment in Nigeria as a good number of people employed by the SMEs are probably under-employed. Conclusively, the inability of our commercial banks to grant effective loans to SMEs have translated to low level of output of SMEs to GDP. This in turn has impacted negatively on average capacity utilization and a consequent hike in the already strained unemployment situation in Nigeria. While commercial banks are expected to come to the rescue of SMEs, the truth must be said, that these institutions are profit oriented and may not be in a vantage position to give long term loans with depositors funds that are predominantly short tenured. Based on the findings of study, it is recommended that, the intervention programs put in place by the Small and Medium Enterprises Development Agency of Nigeria (SMEDAN) to ameliorate the challenges of the SMEs should be strengthened. It is not out of place too, for commercial banks to re-jig their SME desks in order to offer sustainable financial assistance to the SMEs. Lastly, the Bank of Industry (BOI) should be properly positioned in its mandate of providing financial assistance for the establishment of large, medium and small projects as well as the expansion, diversification and modernization of existing enterprises and to rehabilitate the ailing ones.
\end{abstract}

Keywords: Small and medium scale enterprises (SMEs), Commercial bank loans, Output of small and medium scale enterprises, Bank of Industry, Inflation, Interest and Exchange rates 


\section{Background of the study}

Though the Nigerian economy is run majorly on the proceeds from her oil wealth, she still relies on pockets of corporate organizations ranging from the multinationals to indigenous manufacturing companies and the SMEs.

Small and Medium scale Enterprises (SMEs) can best be described through their capital base, scope and cost of projects, annual turnover, financial strength and number of employees amongst other things. They out number large firms considerably, employ vast numbers of people and are generally entrepreneurial in nature, helping to shape innovation Some of the business groups that fall under the scope of medium scale industry include soap production, hair/body cream production, chemical production, commercial poultry, and professional practices such as law, accounting and education. Others are the food and beverage sector etc. ( www.investopbia.com).

SMEs exist in the form of sole proprietorship and partnership, though some could be registered as limited liability companies. They form the bulk of the businesses in Nigeria. This is so because they are less capital intensive and flexible in filling the need in niche markets. Thus, the essence of this study is to appraise the impact of commercial bank loans on the operations and performance of small and medium scale enterprises in Nigeria.

\section{Statement of the research problem.}

Notwithstanding the acknowledged role of SMEs, a number of factors limit their growth potentials. They're still faced with the issue of funding and to overcome this problem, external borrowing has become inevitable. This study intends to appraise the circumstances surrounding the inability of commercial banks to effectively fund the activities of the SMEs in Nigeria. That is the crux of the matter!

\subsection{Objectives of the study}

The main objectives of this study include:

- To ascertain the effect of inadequate financing by commercial banks on the performance of SMEs in Nigeria

- To determine the impact of inadequate financing by commercial banks on average capacity utilization of SMEs in Nigeria.

- To find out if the proliferation of SMEs is helping to curb the rate of unemployment in Nigeria.

\subsection{Research questions}

In line with the above objectives, this research work aims at answering the following questions:

- Has inadequate financing by commercial banks affected the performance of SMEs in Nigeria?

- Has inadequate financing by commercial banks impacted on capacity utilization of SMEs in Nigeria?

- Has the upsurge in the activities of SMEs helped to curb unemployment in Nigeria?

\subsection{Hypotheses of the study}

Ho1: Commercial bank loans do not have any significant impact on the output of SMEs in Nigeria $\mathbf{H o}_{2}$ : Inadequate financing of SMEs by commercial banks do not have any significant impact on average capacity utilization in Nigeria

$\mathbf{H o}_{3}$ : Upsurge in the operations of SMEs have not led to a significant reduction in unemployment rate in Nigeria 


\subsection{Significance of the study}

The study of problems and prospect of SMEs is relevant to the governments (be it at the federal, state and local government levels). It is also important to policy makers; Owners of Small and Medium scale Enterprise and, financial institutions. Not only will this study invoke interests and debates on the problems and prospects of SMEs in Nigeria, it will also serve as reference materials for future and further works in this area. Thus identifying and analysing the key problems of the SMEs would lay a solid foundation for problems mitigation or solving them out rightly.

\subsection{Scope of the study}

This discuss is a broad one; it is however limited only to the Nigerian context. Period of study is delineated from 1990 to 2019. Variables used in the study includes: industry output, employment generations, and capacity utilization and macro-economic variables that served as control tools.

\section{Literature Review}

\subsection{Conceptual framework}

SMEs in Nigeria are seen as the backbone of the economy and a key source of economic growth, dynamism and flexibility. Indeed, there appears to be an agreement that the development of SMEs in Nigeria is a step towards building a vibrant and diversified economy. According to the Federal Ministry of Commerce and Industry, SMEs are defined as firms with a total investment (excluding cost of land but including capital) of up to N750, 000, and paid employment of up to fifty (50) persons. SMEs exist in the form of sole proprietorship and partnership, though some could be registered as limited liability companies and characterized by: simple management structure, informal employer/employee relationship, labour intensive operation, and simple technology, fusion of ownership and management and limited access to capital.

\subsubsection{Role of SMES in the economic development of Nigeria}

Though it may be difficult to obtain exact and comparable figures on SMEs for a developing country like Nigeria, it is very obvious that they play tangible roles in the economic development of the nation. The vital roles played by SMEs have elicited the drums of support and assistance from Nigerian governments. SMEs are valid source of employment generation, development of indigenous technology, even dispersal of industrial set ups, increased production of manufacturing exports, and increasing local content of industrial output by fostering forward and backward industrial linkages to enhance the general level of economic activities. Thus, the specific roles of SMEs include:

- Employment generation

- Output expansion

- Utilization of total resources

- Transformation of indigenous technology

- Production of intermediate goods

- Contribution to government revenue base and

- Rural development acceleration through wide industrial dispersal and others.

Successive governments in Nigeria have recognized the very important role of SMEs and had come up with policy initiatives aimed at promoting their cause. The most tangible of them all was the focus on enhancing the financial assistance and support to the SMEs and the establishment of the Small and Medium Enterprises Development Agency of Nigeria (SMEDAN) to ameliorate the challenges of the SMEs.

\subsubsection{Problems of SMEs in Nigeria}


Despite the catalytic role of SMEs in the economic emancipation of countries, some of their operational challenges in Nigeria Include:

- Lack of trained manpower and management skills.

- Most Nigerian Entrepreneurs do not have the investment culture of ploughing back profits.

- SMEs often do not carry out proper strategic planning in their operations.

- The high rents charged by store owners on good locations have forced real small-scale operators into the streets or at best into accessible places.

- The accounting system of most SMEs lack standards hence, no proper assessment of their performances.

- SMEs are face with the problems of double taxation. This has in no small measure increased the cost of doing business.

- Instability in government policies have in no small measure made some SMEs to collapse.

- SMEs are still faced with the issue of funding and to overcome this problem, external borrowing has become inevitable. Commercial banks appear to be the most likely source of funds. While commercial banks are expected to come to the rescue of SMEs, the truth must be said, that these institutions are profit oriented and may not be in a vantage position to give long term loans with depositors funds that are predominantly short tenured.

\subsubsection{Prospect of SMEs in Nigeria}

In spite of the aforementioned problems of SMEs, it has been acknowledged that they help to create employment opportunities for the teeming unemployed youths in Nigeria. They are equally contributing to the economic growth and development of Nigeria. For entrepreneurs to experience valid growths and to contribute meaningfully to the Nigerian economy, they must be ready to acquire the necessary basic skills and training. Some of the entrepreneurs have need for a formal higher education

\subsection{Theoretical Framework}

In this study we will review briefly, the pecking order and financial led growth theories:

\section{The pecking order theory}

This theory opines that firms need to prioritize their sources of financing from internal (cash flow or entrepreneur's own capital) to external funding.

\section{Financial Led Growth Theory}

The financial led growth theory believes that the activities of the financial institutions serve as a useful tool for increasing the productive capacity of the economy. They argued that countries with better developed financial system tend to grow faster.

\subsection{Empirical Review}

The outcomes of related but extant studies are briefly reviewed below:

Ikon and Chukwu (2018) did a study on the Infrastructural constraints that militate against efficient performance of SMEs in the country. Findings of study revealed that manufacturing SMEs has a statistical significant relationship with industrial growth in Nigeria. Okuneye, and Ogunmuyiwa (2016) examined the factors that determine the growth of SMEs in Nigeria for the period 1980-2013. Outcome of the study suggest that credit facilities, interest rate as well as inflation rate are key determinants of the growth and survival of SMEs in Nigeria. Ogbuanu, Kabuoh and Okwu (2014), investigated the relevance of the manufacturing SMEs to the growth 
of the Nigerian economy. Results of the study showed that the manufacturing SMEs made sizable contributions to the sustained increases in gross domestic product.

Afolabi (2013) investigated the growth effect of SMEs financing in Nigeria. The result of study revealed that the variables - SMEs output by wholesale and retail trade as a component of GDP, commercial banks credit to SME and exchange rate of naira to the US dollar exert positive influence on economic development. Onyeiwu (2012) reviewed the impact of SMEs financing on the economic growth of Nigeria Outcome of study revealed that loans to SMEs and other variables except money supply and deficit financing exerted a positive impact on GDP growth. Duru and lawal (2012) accessed the impact of financial reforms on the growth of small and medium scale enterprise in Nigeria. The study recommended that government should create an enabling environment to ease the cost of doing business in Nigeria. Lastly, Abiola et al. (2011) investigated the contributions of micro finance banks to the development of SMEs in Lagos and Ogun state of Nigeria. The result obtains showed that there is a low positive correlation between micro loan received by entrepreneurs and business expansion of MSMES in Nigeria.

\section{Methodology}

An ex-post facto research design was adopted in this study. A least square regression analysis was carried out on a time-series data. The following relationship model is adopted thus:

\section{OPSME $=$ bo $+b_{1}$ CBLSME $+b_{2}$ ACUT $+b_{3}$ UNEMPL+ $b_{4}$ INTR $+b_{5}$ INFL+ $b_{6}$ EXCHR+e Equation 1}

Where:

OPSME = Output of small and medium scale enterprises

CBLSME = Commercial bank loans to small and medium enterprises

ACUT $=$ Average Capacity utilization

UNEMP $=$ Unemployment rate

INTR = Interest rate

INFL=Inflationary rate

$\mathbf{E X C H R}=$ Exchange rate

$\mathbf{e}=$ Error term

OPSME was the dependent variable in the test of hypotheses 1 and 2 while CBLSME was the dependent variable in the test of hypothesis 3. ACUT, UNEMP are the independent variables, while INTR, INFL and EXCHR constitute the control variables. A least square regression analysis was use to test the coefficients of equation.

\subsection{Justification of the chosen variables}

In this study we intend to use one (1) dependent, three (3) independent and three control variables to ascertain relationships.

\section{Output of Small and Medium Scale Enterprises (OPSME)}

According to an official data from the World Bank group, SMEs in Nigeria contributed about $48 \%$ of the country's gross domestic product (GDP) in 2018. In reality the output of SMEs to GDP of Nigeria could be far higher than $48 \%$, but for purpose of this study we have articulated and adopted $48 \%$ as the benchmark contribution of SMEs to Gross Domestic Product (GDP) in Nigeria for the period under review. A trend review of the outputs of SMEs in Nigeria is aptly captured in figure 1 below: 
Kanu Success Ikechi, Nwadiubu Anthony

Commercial Bank Loans and the Performance of Small and Medium Scale Enterprises (SMEs) In Nigeria

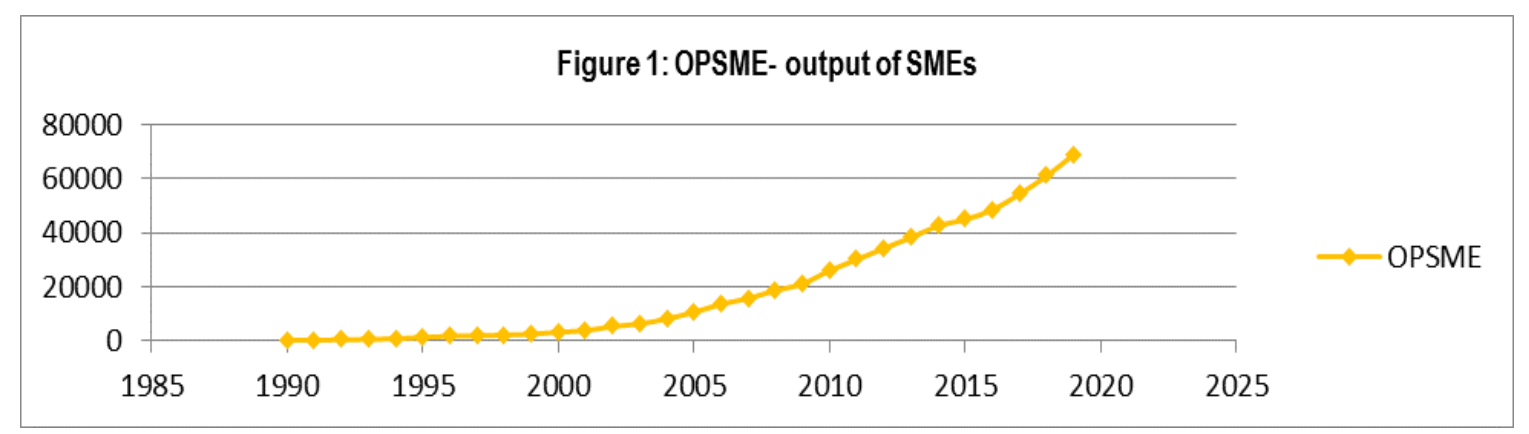

Source: 2019 CBN Statistical Bulletin

\section{Commercial Bank loans to SMEs}

This refers to credit facilities availed the small and medium-term enterprises to enable them overcome their financial constraints and challenges. Going by the trend review in figure 2 below, one can rightly say that commercial bank loan to SMEs may not have been too impressive. It has faced some hiccups overtime. While commercial banks are expected to come to the rescue of SMEs, the truth must be said, that these institutions are profit oriented and may not be in a vantage position to give long term loans with depositors' funds that are predominantly short tenured.

A trend review of commercial bank loans to SMEs in Nigeria are aptly captured in figure 2 below:

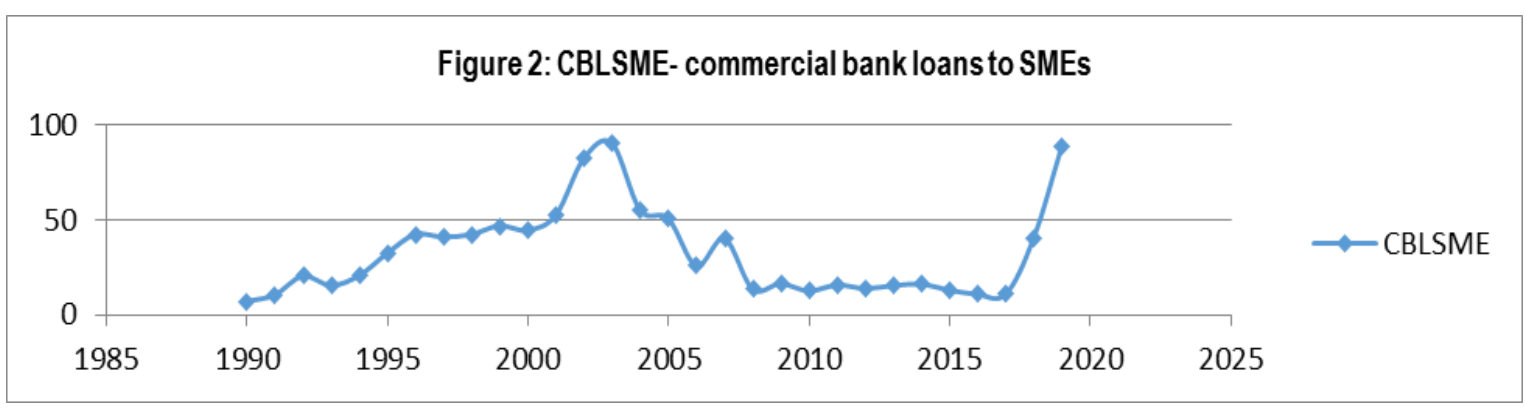

Source: 2019 CBN Statistical Bulletin

\section{Average Capacity Utilization (ACUT):}

Capacity utilization could be defined as a ratio of the actual level of output to a sustainable maximum level of output, or capacity. A trend review of average capacity utilization in Nigeria is given in figure 3 below:

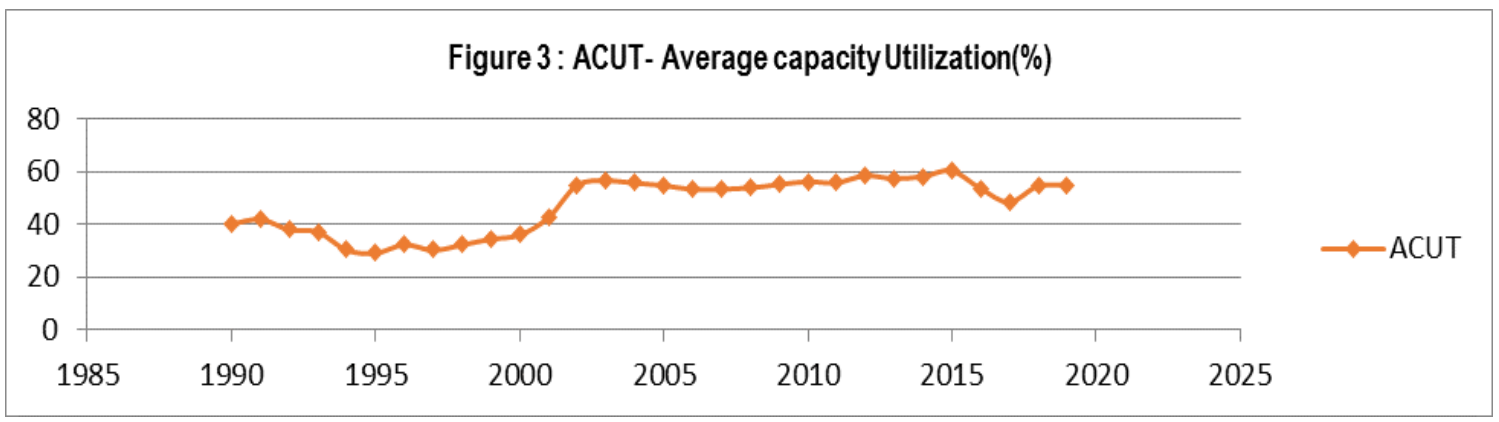

Source: 2019 CBN Statistical Bulletin 


\section{Unemployment Rate (UNEMP):}

This refers to the percentage of the total labour force that is employed but actively seeking employment and willing to work. A trend review of unemployment rate in Nigeria is given in figure 4 below:

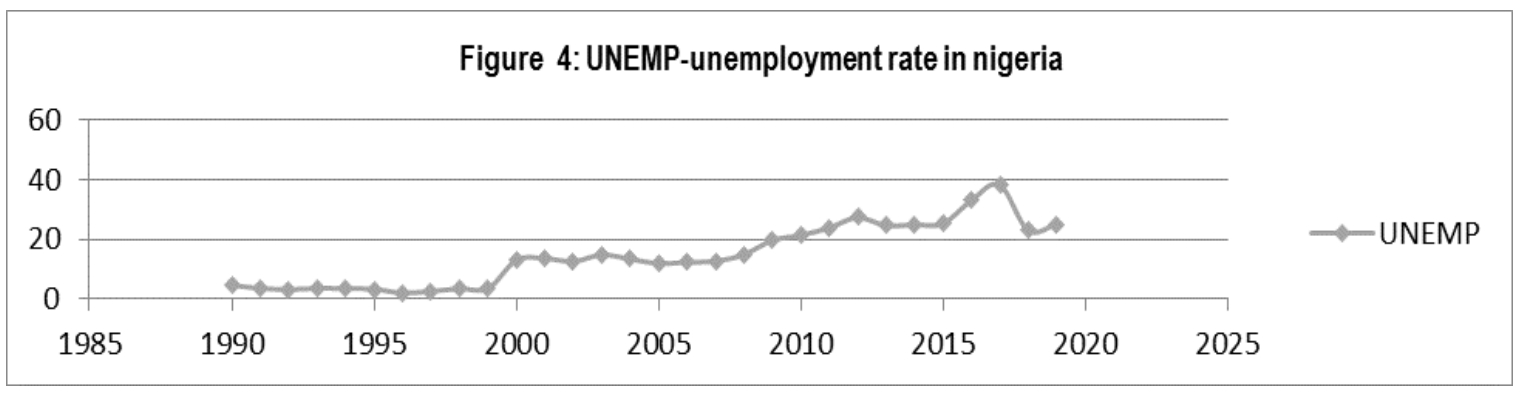

Source: Source: 2019 CBN Statistical Bulletin

Figure 5: The control variables: Interest, inflation and Exchange rates:

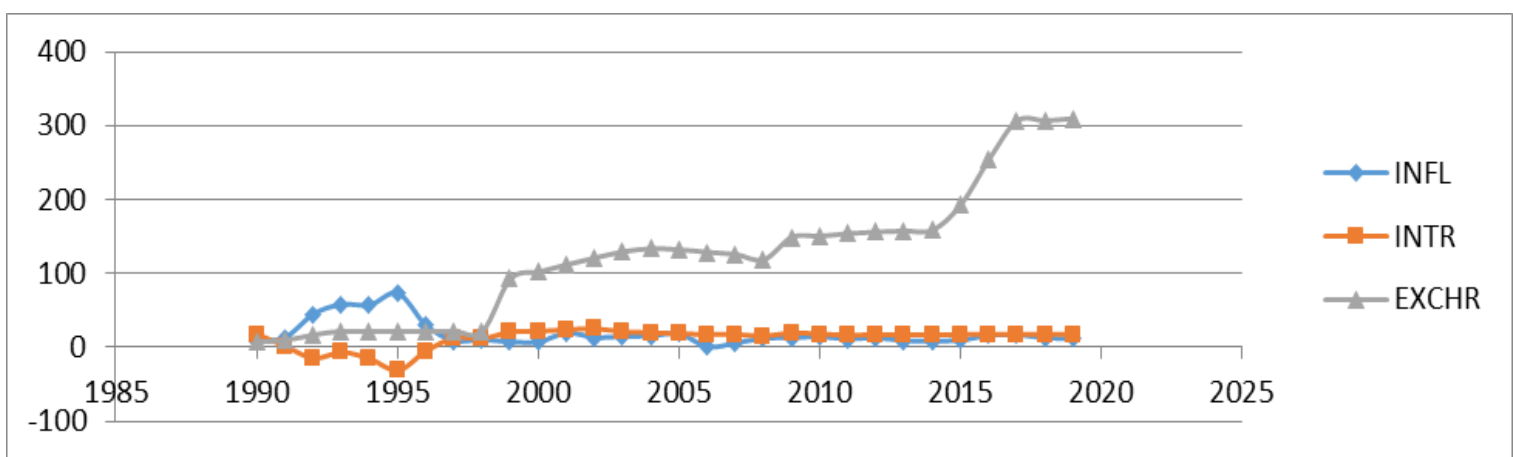

Source: 2019 CBN Statistical Bulletin

Interest, inflation and exchange rates are basic macroeconomic variables inputted into this study to act as control variables. Our dependent and independent variables cannot operate in isolation or devoid of the impact of the aforementioned control variables. The central bank of Nigeria through her monetary policy statements have been working towards achieving a stable interest and inflation rates but to a large extent, that of exchange rate is left for the market forces to determine and that explains the wild volatilities / vagaries associated with exchange rates as exemplified in figure 5 above.

\subsection{Expected or Apriori expectations}

In line with the above justification of chosen variables, it is expected that increased bank credits and consequent improved or enhanced capacity utilization will help to increase the output of small and medium scale enterprises and to a large extent help to curb the rate of unemployment in Nigeria.

\section{Data analysis, results and discussion}

The data for our estimation were obtained from CBN Statistical Bulletin and other publications from SMEDAN. The scope of study was delineated from January, 1990 to 2019, a total of 30 years. A combination of preliminary and short run models was generated in this investigation.

Table 1 below shows the unit root test for stationarity using Augmented Dickey-Fuller test. Two (2) out of the seven (7) variables i.e. (Interest and inflation rates) turned stationary at first difference while the rest became stationery at second difference. 
Table 1: Summary of unit root test

\begin{tabular}{|l|l|l|l|l|l|l|}
\hline Variable & $\begin{array}{l}\text { ADF } \\
\text { T- } \\
\text { statistics }\end{array}$ & $\begin{array}{l}\text { Critical } \\
\text { value@1\% }\end{array}$ & $\begin{array}{l}\text { Critical } \\
\text { value@5\% } \%\end{array}$ & $\begin{array}{l}\text { Critical } \\
\text { value@ } \\
\%\end{array}$ \\
\hline CBLME & -8.40 & -3.70 & -2.98 & -2.63 & $\begin{array}{l}\text { Order of } \\
\text { co-integration }\end{array}$ & $\begin{array}{l}\text { Level of } \\
\text { Significance }\end{array}$ \\
\hline OPSME & -6.27 & -3.70 & -2.98 & -2.63 & $2^{\text {nd }}$ difference & significant \\
\hline ACUT & -6.16 & -3.71 & -2.98 & -2.63 & $2^{\text {nd }}$ difference & signnificant \\
\hline UNEMP & -7.09 & -3.71 & -2.98 & -2.63 & $2^{\text {nd }}$ difference & significant \\
\hline INTR & -7.35 & -3.77 & -3.00 & -2.64 & $1^{\text {st }}$ difference & significant \\
\hline INFL & -10.27 & -3.97 & -3.08 & -2.68 & $1^{\text {st }}$ difference & significant \\
\hline EXCHR & -6.80 & -3.70 & -2.97 & -2.63 & $2^{\text {nd }}$ difference & significant \\
\hline
\end{tabular}

Source: E-views statistical package version 9

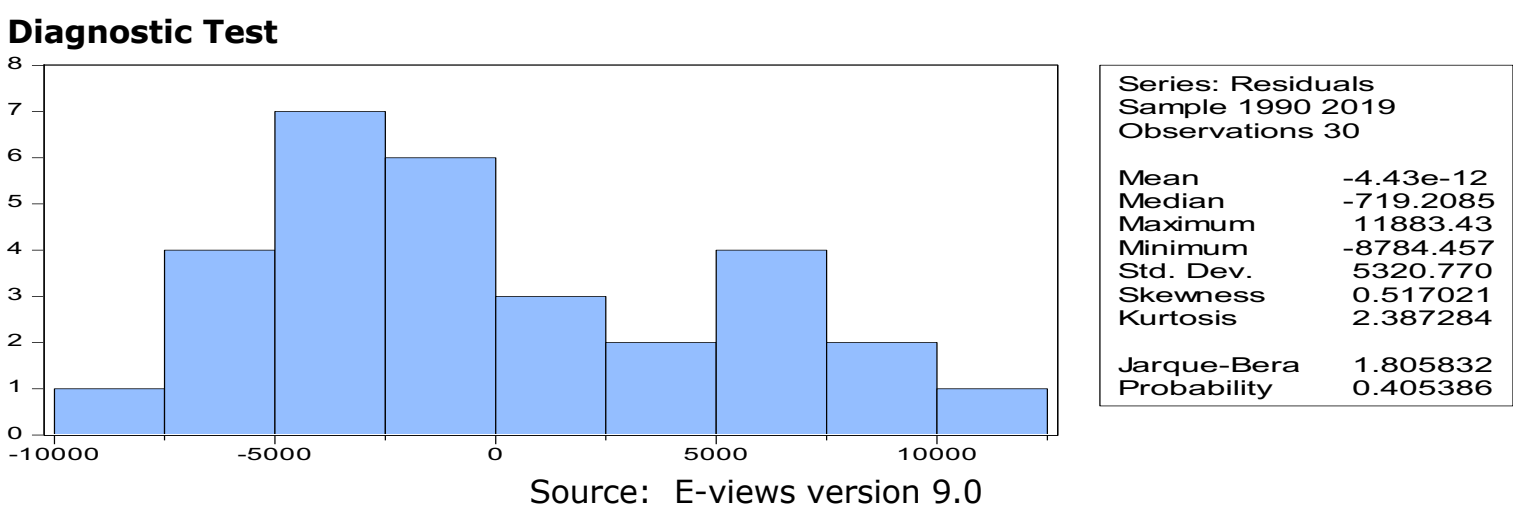

The above normality test suggests that, to some extent the series are normally distributed.

Table 3: Heteroskedasticity Test: White

\begin{tabular}{|c|c|c|c|}
\hline F-statistic & 2.296842 & Prob. $F(27,2)$ & 0.3485 \\
\hline Obs*R-squared & 29.06272 & Prob. Chi-Square(27) & 0.3579 \\
\hline
\end{tabular}

Table 3 above reveals that the p-value of about $35 \%$ is greater than the critical value of $5 \%$. This shows that there is no evidence for the presence of Heteroskedasticity since the P-values are considerably in excess of 0.05 .

\section{Table 4: Johansen CO-integration test}

Result of Johansen co-integration tests below strongly reject the null hypothesis of no cointegration i.e. no long run relationships. In other words, there exist long run relationships between the dependent and independent variables.

Table 4 below suggests the existence of long run relationships between the variables under review. To be precise, there exist at most 4 co-integrating equations in both the trace and max -Eigen value rank tests. 


\begin{tabular}{|l|l|l|l|}
\hline Relationships between variables & $\begin{array}{l}\text { No. of co- integrating } \\
\text { Equations. (Trace Test) }\end{array}$ & $\begin{array}{l}\text { No. of co- integrating } \\
\text { Equations (Maximum } \\
\text { Eigenvalue test) }\end{array}$ & $\begin{array}{l}\text { Nature of } \\
\text { Equilibrium }\end{array}$ \\
\hline $\begin{array}{l}\text { Commercial Bank loans and the } \\
\text { performance of SMEs in Nigeria }\end{array}$ & $\begin{array}{l}\text { There exist at most } 4 \\
\text { co integrating equations }\end{array}$ & $\begin{array}{l}\text { There exist at most } 4 \\
\text { Co-integrating } \\
\text { equations }\end{array}$ & Long-run \\
\hline
\end{tabular}

Now that we are through with the preliminary tests, next is to ascertain the relationships between the dependent and independent variables. To be able to do that we need to restate the hypotheses of study for purpose of achieving clarity

Ho1: Commercial bank loans do not have any significant impact on the output of SMEs in Nigeria. $\mathbf{H o}_{2}$ : Inadequate financing of SMEs do not have any significant impact on Average Capacity Utilization in Nigeria

$\mathbf{H o}_{3}$ : Upsurge in the operations of SMEs have not led to a significant reduction in unemployment in Nigeria

\section{Test of Hypothesis 1}

Commercial bank loans do not have any significant impact on the output of SMEs in Nigeria

Table 5: Ordinary Least Square Regression Analysis

Dependent Variable: CBLSME

Method: Least Squares

\begin{tabular}{lllll}
\hline \hline Variable & Coefficient & Std. Error & t-Statistic & Prob. \\
\hline \hline C & 7.215891 & 24.83400 & 0.290565 & 0.7741 \\
OPSME & -0.000719 & 0.000612 & -1.176425 & 0.2520 \\
ACUT & 0.403774 & 0.546570 & 0.738741 & 0.4679 \\
UNEMP & -3.179338 & 0.891081 & -3.567956 & 0.0017 \\
INFL & 0.277243 & 0.595961 & 0.465203 & 0.6464 \\
INTR & 0.596942 & 0.929544 & 0.642189 & 0.5274 \\
EXCHR & 0.455754 & 0.144798 & 3.147508 & 0.0047 \\
\hline \hline R-squared & 0.567258 & Mean dependent var & 33.12586 \\
Adjusted R-squared & 0.449238 & S.D. dependent var & 24.03634 \\
S.E. of regression & 17.83817 & Akaike info criterion & 8.807064 \\
Sum squared resid & 7000.408 & Schwarz criterion & 9.137100 \\
Log likelihood & -120.7024 & Hannan-Quinn criter. & 8.910427 \\
F-statistic & 4.806444 & Durbin-Watson stat & 1.336674 \\
Prob(F-statistic) & 0.002838 & & & \\
\hline \hline
\end{tabular}

Source: E-view statistical package version9.0

From the above regression analysis; computed $F$ statistics is 4.8 . The regression equation is stated thus: 


\section{CBLSME = 7. $22-0.0007$ OPSME +0.4ACUT - 3.18UNEMP +0.28INFL +0.6 INTR $+0.46 E X C H R$}

The regression equation indicates that there exists an inverse relationship between the amount of commercial bank loans made available to the SMEs and the output of Small and Medium Scale Enterprises / unemployment rates in Nigeria. This implies that as CMBLSME increases, OPSME decreases.

The negative sign exhibited by OPSME is not in line with apriori expectation because an increase in CMBLSME is supposed to cause an increase in investment which is expected to boost the output of SME. This trend has shown the poor attitude of commercial banks towards the granting of loans to small and medium scale enterprises in Nigeria. This has also helped to escalate the level of unemployment situation in Nigeria.

The regression equation also indicates that there is a positive relationship between average capacity utilization, inflation, interest and exchange rates with the amount of commercial bank loans made available to the Small and Medium Scale Enterprises (SMEs) In Nigeria This means that as the amount of commercial bank loans made available to SMEs in increases, there will also be an increase in average capacity utilization, inflation, interest and exchange rates in Nigeria.

\section{Test of goodness of fit using the Adjusted R-Square}

Going by the output of table 5, the Adjusted R-Square is 0.44 . This result indicates that the independent variables included in the model accounted for only $44 \%$ variations in the dependent variable. This is a pointer to the fact that there might be some other variables that ought to have been included in the model or the presence of error terms that are contained therein.

\section{Test of the individual significance using t- test}

Here we stand to test the hypothesis of study thus:

Ho $_{1}$ : Commercial bank loans do not have any significant impact on the output of SMEs in Nigeria. From table 4.1 above, while the $T$-cal of OPSME $=-1.18$; the $\mathrm{T}$ tab $=2.06$ at $5 \%$ Alpha level

Decision Rule: Since t-calculated is less than $\mathrm{t}$ - tabulated, we accept the null hypothesis and reject the alternative. We conclude that commercial bank loans do not have any significant impact on the output of SMEs in Nigeria.

\section{Test of Hypothesis 2}

$\mathbf{H o}_{2}$ : Inadequate financing of SMEs do not have any significant impact on average capacity utilization in Nigeria

From table 4.1 above; while the $\mathrm{T}$-cal of ACUT $=0.74$; the $\mathrm{T}$ tab $=2.06$ at $5 \%$ Alpha level Decision Rule: Since t-calculated is less than the t- tabulated, we accept the null hypothesis and reject the alternate. We conclude that Inadequate financing of SMEs do not have any significant impact on average capacity utilization in Nigeria. 
Table 6: Ordinary Least Square Regression Analysis

Dependent Variable: OPSME -

Method: Least Squares

\begin{tabular}{lllll}
\hline \hline Variable & Coefficient & Std. Error & t-Statistic & Prob. \\
\hline \hline C & 7912.615 & 8242.178 & 0.960015 & 0.3475 \\
CBLSME & -82.25835 & 69.92231 & -1.176425 & 0.2520 \\
ACUT & 107.1477 & 185.6863 & 0.577036 & 0.5698 \\
UNEMP & 289.5034 & 373.4948 & 0.775120 & 0.4465 \\
EXCHR & 215.0425 & 37.07416 & 5.800334 & 0.0000 \\
INFL & -549.2947 & 165.1975 & -3.325080 & 0.0031 \\
INTR & -968.5126 & 240.8306 & -4.021552 & 0.0006 \\
\hline \hline R-squared & 0.936885 & Mean dependent var & 19220.55 \\
Adjusted R-squared & 0.919671 & S.D. dependent var & 21280.89 \\
S.E. of regression & 6031.499 & Akaike info criterion & 20.45388 \\
Sum squared resid & $8.00 E+08$ & Schwarz criterion & 20.78392 \\
Log likelihood & -289.5813 & Hannan-Quinn criter. & 20.55725 \\
F-statistic & 54.42795 & Durbin-Watson stat & 1.292842 \\
Prob(F-statistic) & 0.000000 & & & \\
\hline \hline
\end{tabular}

Source: e-views statistical package version 9.0

From the above regression analysis; computed $\mathrm{F}$ statistics is 54.4 . The regression equation is stated thus:

\section{OPSME $=7912.62-82.26 C B L S M E+107.15$ ACUT + 289.5UNEMP -549.29 INFL - 968.5 INTR + 215EXCHR}

The regression equation indicates that there exists an inverse relationship between the output of Small and Medium Scale Enterprises, inflation and interest rates. This implies that as OPSME increases, CMBLSME, interest inflationary rates decrease. The negative sign exhibited by CBLSME, interest and inflationary rates are not in line with our prior expectation.

The regression equation also indicates that there is a positive relationship between the output of small and medium scale enterprises and average capacity utilization, unemployment and exchange rates. The implication of this trend is that as the output of Small and Medium Scale Enterprises increases, there will also be an increase in average capacity utilization, unemployment and exchange rates in Nigeria.

The turnout of events as it relates to the spiralling rate of unemployment rate is understandable. A good number of people employed by the SMEs are probably under employed.

\section{Test of goodness of fit using the Adjusted R-Square}

Going by the output of table 6 , the Adjusted R-Square is 0.92 . This result indicates that the independent variables included in the model accounted for about $92 \%$ variations in the dependent variable.

\section{Test of individual significance using t- test}


Here we stand to test the hypothesis of study thus:

$\mathrm{Ho}_{3}$ : Upsurge in the operations of SMEs have not led to a significant reduction in unemployment rate in Nigeria

From table 4.2 above, while the $T$-cal of UNEMP $=0.78$; the $T$ tab $=2.06$ at $5 \%$ Alpha level

Decision Rule: Since t-calculated is less than t- tabulated, we accept the null hypothesis and reject the alternative. We conclude that the seeming upsurge in the operations of SMEs have not led to a significant reduction in unemployment rate in Nigeria.

\section{Discussion of findings}

Outcome of study has shown that SMEs have a lot to offer in terms of helping the Nigerian economy to grow but their performance and subsequent output to economic growth is hampered by the lack of sustainable financial assistance from commercial banks operating in the land. The SMEs have been in the forefront of providing employing opportunities to our teeming youths but their present financial predicament is limiting them from achieving these desirable objectives and to attain their full potentials. Thus, capacity utilization has remained low. Result of study is in tandem with the outcome of other previous studies in the Nigerian context. The obvious question now is - What is the best foot forward in bridging this financial gap?

\section{Summary, conclusion and recommendations}

The outcomes of this study are itemized below:

- The regression equation indicates that there exists an inverse relationship between the amounts of commercial bank loans made available to the SMEs and the output of Small and Medium Scale Enterprises/ unemployment rate in Nigeria. This implies that as OPSME increases, CMBLSME decreases. The negative sign exhibited by OPSME is not in line with prior expectation because an increase in CMBLSME is supposed to cause an increase in investment which is expected to boost the output of SME. This trend has shown the poor attitude of commercial banks towards the granting of loans to small and medium scale enterprises in Nigeria. This has also helped to escalate the level of unemployment situation in Nigeria.

- The regression equation also indicates that there is a positive relationship between average capacity utilization, inflation, interest and exchange rates with the amount of commercial bank loans made available to the SMEs in Nigeria This means that as the amount of commercial bank loans made available to SMEs in increases, there will also be an increase in average capacity utilization, inflation, interest and exchange rates in Nigeria.

- There is an inverse relationship between the output of SMEs and inflation/ interest rates.

- There is a positive relationship between the output of small and medium scale enterprises and average capacity utilization, unemployment and exchange rates. The implication of this trend is that as the output of Small and Medium Scale Enterprises increases, there will also be an increase in average capacity utilization, unemployment and exchange rates in Nigeria.

- The seeming upsurge in the operations of SMEs did not lead to a significant reduction in unemployment rate in Nigeria. To some extent, a large chunk of the people employed by SMEs are under employed

\subsection{Conclusion}

The seeming inability of our commercial banks to grant effective loans to SMEs translates to a low level of output or contribution of SMEs to GDP. This in turn impacts negatively on average capacity utilization. The Low-level capacity utilization in turn translates to a high level of unemployment rate; thereby escalating the already strained unemployment situation in Nigeria. This study recognizes the dearth of funds as one of the major problems of SMEs in Nigeria. 


\subsection{Recommendations}

Based on the findings of study, the following recommendations are made.

1. Through proper policy implementation by government, banks could be made, to extend the much-required funds to SMEs with little or no collateral. Commercial banks need to re-jig their SME desks in order to offer sustainable financial assistance to the SMEs. Banks can afford to enter into venture capital arrangement with the SMEs

2. The employment potentials of the SMEs could be nurtured and sustained through honest implementation of the policy measures established to support the SMEs.

3. SMEs need to be adequately harnessed and encouraged to fully achieve their full potentials and capacity utilization.

4. The intervention programs put in place by the Small and Medium Enterprises Development Agency of Nigeria (SMEDAN) to ameliorate the challenges of the SMEs should be strengthened. 5. Lastly, the Bank of Industry (BOI) should be properly positioned in its mandate of providing financial assistance for the establishment of large, medium and small projects as well as the expansion, diversification and modernization of existing enterprises and to rehabilitate the ailing ones.

\section{References}

- Abel, S., \& Le Roux, P. (2016). Determinants of banking sector profitability in Zimbabwe. International Journal of Economics and Financial Issues, 6(3).

- Babajide, A. A., Iyoha, F. O., \& Taiwo, J. N. (2011). Microfinance and Micro, Small and Medium Enterprises Development in Nigeria. A quarterly Journal of Association of National Accountants of Nigeria, 19.

- Jaja, s. A., \& momodu, a. (2003). The impact of monetary polices on the performance of indigenous financial organisations: a focus on the nigerian merchant banks. Nigerian Journal of Management Sciences Vol. IV, 157.

- Afolabi, M. O. (2013). Growth effect of small and medium enterprises (SMEs) financing in Nigeria. Journal of African Macroeconomic Review, 3(1).

- Akinnawo ,G(2003)" Importance of functional infrastructure and institutions for the survival of SME's in Nigeria, " A seminar paper.

- Samson, A. Y., Olubunmi, A. B., \& Adekunle, O. A. (2013). Microfinance bank as a catalyst for entrepreneurship development in Nigeria: Evidence from Ogun State. International Journal of Business and Social Science, 4(12).

- Amajoyi C,K (2004), 'The impact of commercial banks credit on the growth of small and medium scale Enterprises in Nigeria (1992-2001)", An unpublished project work submitted to the department of Economics, Imo state University, Owerri.

- Beck, T. (2007, April). Financing constraints of SMEs in developing countries: Evidence, determinants and solutions. In KDI 36th Anniversary International Conference.

- Ademokoya, A. A., Sanni, M., Oke, L. A., \& Abogun, S. (2020). Impact of Monetary Policy on Bank Credit in Nigeria. Journal of Accounting Research, Organization and Economics, 3(3), 196-205. Crossref

- Coco, G. (2000). On the use of collateral. Journal of Economic Surveys, 14(2). Crossref

- Chan, Y. S., \& Kanatas, G. (1985). Asymmetric valuations and the role of collateral in loan agreements. Journal of money, credit and banking, 17(1). Crossref

- Cressy, R., \& Olofsson, C. (1997). The financial conditions for Swedish SMEs: Survey and research agenda. Small business economics, 9(2), 179-192. Retrieved from http// link.springler. com. article. $\underline{\text { Crossref }}$

- Duru, M., \& Lawal, M. K. (2012). Financial sector reforms and the growth of small and medium scale enterprises (SMEs) in Nigeria. Universal Journal of Management and Social Sciences, 2(8). 
- Abraham, H., \& Balogun, I. O. (2012). Contribution of microfinance to GDP in Nigeria: Is there any. International Journal of Business and Social Science, 3(17). survey, Retrieved from http// www.efina.org.ng/

- Olusegun, A. I. (2012). Is small and medium enterprises (SMEs) an entrepreneurship?. International Journal of Academic Research in Business and Social Sciences, 2(1), 487.

- Ogechukwu, A. D. (2011). The role of small scale industry in national development in Nigeria. Universal Journal of Management and Social Sciences, 1(1), 23-41.

- Ehikioya, I. L., \& Mohammed, I. (2013). Commercial bank credit accessibility and sectoral output performance in a deregulated financial market economy: Empirical evidence from Nigeria. Journal of Finance and Bank Management, 1(2), 36-59..

- CHINEDU, O. T. (2016). INDUSTRIALIZATION AND ECONOMIC GROWTH IN NIGERIA (19812014).

- CHINEDU, O. T. (2016). INDUSTRIALIZATION AND ECONOMIC GROWTH IN NIGERIA (19812014).

- Ayodele, T. D., \& Alabi, R. O. (2014). Risk management in Nigeria banking industry. Risk Management, 5(2).

- Njoku, P.N 2012), Bank lending and credit Administration, Owerri, Concas publishers.

- Ogujiuba K.K, Ohuche,F.K and Adenuga A,O (2004), Credit availability to small and medium scale enterprises in Nigeria: Importance of new capital base for banks, backgrounds and issues", AIAE Working papers.

- Onyeiwu, C. (2012). Small and Medium Scale Enterprises Finance and Economic Development in Nigeria. Downloaded via Google at chasoyeiwu@yahoo.com

- Schumpeter, J., \& Backhaus, U. (2003). The theory of economic development. In Joseph Alois Schumpeter. Springer, Boston, MA. Crossref

- Stiglitz, J. E., \& Weiss, A. (1981). Credit rationing in markets with imperfect information. The American economic review, 71(3).

- Beck, T. (2007, April). Financing constraints of SMEs in developing countries: Evidence, determinants and solutions. In KDI 36th Anniversary International Conference.

- World Bank (1995): "Nigeria: A diagnostic Review of the small and Medium scale Enterprise sector, in Nnanna, O..J. (2001). 